\title{
Mecasermin in Insulin Receptor-Related Severe Insulin Resistance Syndromes: Case Report and Review of the Literature
}

\author{
Michaela Plamper, Bettina Gohlke, Felix Schreiner and Joachim Woelfle * \\ Pediatric Endocrinology and Diabetology Division, Children's Hospital, University of Bonn, Adenauerallee 119, \\ 53113 Bonn, Germany; Michaela.Plamper@ukbonn.de (M.P.); Bettina.Gohlke@ukbonn.de (B.G.); \\ Felix.Schreiner@ukbonn.de (F.S.) \\ * Correspondence: Joachim.Woelfle@ukb.uni-bonn.de; Tel.: +49-228-2873-3223; Fax: +49-228-2873-3472
}

Received: 8 March 2018; Accepted: 18 April 2018; Published: 24 April 2018

\begin{abstract}
Mutations in the insulin receptor (INSR) gene underlie rare severe INSR-related insulin resistance syndromes (SIR), including insulin resistance type A, Rabson-Mendenhall syndrome and Donohue syndrome (DS), with DS representing the most severe form of insulin resistance. Treatment of these cases is challenging, with the majority of DS patients dying within the first two years of life. rhIGF-I (mecasermin) has been reported to improve metabolic control and increase lifespan in DS patients. A case report and literature review were completed. We present a case involving a male patient with DS, harbouring a homozygous mutation in the INSR gene (c.591delC). Initial rhIGF-I application via BID (twice daily) injection was unsatisfactory, but continuous subcutaneous rhIGF-I infusion via an insulin pump improved weight development and diabetes control (HbA1c decreased from 10 to $7.6 \%$ ). However, our patient died at 22 months of age during the course of a respiratory infection in in Libya. Currently available data in the literature comprising more than 30 treated patients worldwide seem to support a trial of rhIGF-I in SIR. rhIGF-I represents a treatment option for challenging SIR cases, but careful consideration of the therapeutic benefits and the burden of the disease is warranted. Continuous application via pump might be advantageous compared to single injections.
\end{abstract}

Keywords: severe insulin resistance syndromes; Donohue syndrome; mecasermin; rhIGF-I

\section{Introduction}

The etiology and clinical presentation of severe insulin resistance is highly variable [1], with severe insulin receptor (INSR)-related insulin resistance syndromes (SIR) exhibiting a peculiar phenotypical spectrum. Within SIR, there is a continuum of insulin resistance, ranging from Donohue syndrome (DS) with no remaining insulin receptor function to the milder phenotypes of Rabson-Mendenhall syndrome (RMS) and type A insulin resistance [2,3].

Donohue syndrome was initially described in 1948 and 1954 by Donohue and Uchida [4]. Patients with DS exhibit severe intrauterine and postnatal growth retardation. Infants present with typical facial feature, resembling Leprechaun's elves of Irish fairy tales, with lipoatrophy, acanthosis nigricans, hypertrichosis and severe hyperinsulinism, postprandial hyperglycemia and fasting hypoglycemia (for further clinical characteristics see Table 1). Most children with DS die within the first two years of life, mostly during the course of intercurrent infections of the upper airways, hypoglycemia or cardiomyopathy [3,5-8]. To date, there is no causative therapy for this very rare disease available (prevalence of DS $<1: 1$ Mio [9]). Rabson-Mendenhall syndrome was first described 1956 in three siblings with dental and skin abnormalities [10]. Children suffering from 
Rabson-Mendenhall syndrome typically show a milder phenotype [1], including impaired growth, abnormal nails and dentition as well as insulin resistance with acanthosis nigricans and hirsutism. At birth, patients with RMS also show fasting hypoglycemia due to severely increased insulin levels, but with progression of the disease, insulin levels decline [11]. In contrast to DS, patients develop recurrent diabetic ketoacidosis and microvascular complications during the second decade of life [2,5].

Diabetic ketoacidosis does not seem to occur in patients with Donohue syndrome [12], at least not in the first years of life [13]. Type A insulin resistance represents the least severe end of the spectrum [2]. It is usually diagnosed in teenagers or young adults who are not obese, but have severe insulin resistance, acanthosis nigricans, and hyperandrogenism in females. In some, but not all cases, a heterozygous genetic defect in the INSR gene has been reported [3].

Any condition of severe insulin resistance is therapeutically challenging with only limited treatment options being available. High dose insulin [14,15] and metformin [16] have been used in patients with insulin resistance syndromes. Metreleptin has been reported to improve blood glucose levels individuals with Rabson-Mendenhall syndrome [17,18].

Due to the structural similarity of insulin, proinsulin, insulin-like growth factor-I (IGF-I) and IGF-II and resemblances of the insulin and IGF-I receptor, IGF-I was proposed as another treatment option for patients with severe insulin resistance [19-21]. IGF-I use was first reported in the 1990s as an experimental treatment for patients with SIR, mostly with type A insulin resistance [22-28]. In the majority of the available case descriptions of SIR, an improvement in glucose homeostasis and a reduction in $\mathrm{HbA1c}$ was reported [21]. In addition to type A insulin resistance, mecasermin treatment of few patients with congenital insulin resistance syndromes with biallelic mutations within the insulin receptor gene (INSR) has been reported to improve glycemic control and weight gain [29-32] with variable results. In addition to the treatment option for SIR, rhIGF-I has been used previously in patients with growth hormone insensitivity syndrome [33-42]. Since 2008, rhIGF-I has been approved for the treatment of so-called "severe primary IGF-I deficiency" (SPGFD) [43,44].

This paper adds a case description, in which mecasermin treatment via an insulin pump successfully improved glucose homeostasis in a patient with DS and gives an update on the currently available knowledge on the clinical picture, treatment options and complications of these rare insulin resistance syndromes.

\section{Materials and Methods}

A case report and review of existing knowledge regarding the efficiency and safety of mecasermin in insulin receptor-related severe insulin resistance syndromes were completed using a systematic literature review with utilization of PRISMA (Preferred Reporting Items for Systematic Reviews and Meta-analyses) guidelines. We focused on the treatment of patients with DS, and performed a literature research in the Pubmed database using the following search terms:

"mecasermin", "insulin resistance and recombinant IGF-I", "Insulin resistance and recombinant IGF1", "Donohue syndrome and IGF-I", "Donohue syndrome and IGF1", "Rabson-Mendenhall syndrome and IGF-I", "Rabson-Mendenhall syndrome and IGF1", "type A insulin resistance and IGF-I", type A insulin resistance and IGF1".

Thereby, we identified 189 records through database searching and 49 additional records which were identified through other sources, e.g., reference lists of other articles. The removal of duplicates led to 112 remaining records. After screening these records, 81 full-text articles were assessed for eligibility.

All articles were included in the synthesis of this paper. Because all studies reported only small numbers or presented single cases, a systematic meta-analysis could not be performed.

\section{Case Report}

We report on a male infant, who was born at term with a birth weight of $1300 \mathrm{~g}$ ( -3.86 standard deviation scores; SDS) in Tripolis, Libya. At birth, typical dysmorphic features of DS could already be observed. In particular, muscle hypotonia and hyperglycemia with associated hyperinsulinism led to 
a clinical suspicion of an insulin receptor (IR)-related severe insulin resistance syndrome. His parents stated that they were very distantly related but were unable to provide more detailed information. Molecular analysis revealed a homozygous mutation of the insulin receptor gene in exon 2 (c.591delC). This frameshift mutation led to a nonsense mRNA and to a non-functioning insulin receptor, explaining the clinical picture of DS. Initial therapy consisted of a trial with metformin and insulin (no dosages available), which did not exert a relevant effect on glucose homeostasis. The patient presented first at our hospital at an age of 8 months, with a weight of $4020 \mathrm{~g}(<1$ st percentile, $-5.5 \mathrm{SDS})$ and a height of $56 \mathrm{~cm}(<1 \mathrm{st}$ percentile, $-5.61 \mathrm{SDS})$. He was in poor general health and in an extremely dystrophic nutritional state. Despite reduced subcutaneous fat tissue; he exhibited pronounced acanthosis nigricans and hypertrichosis. His skin texture throughout his whole body was remarkably dry and thick. Biochemical analysis revealed an $\mathrm{HbA1c}$ concentration of $10.0 \%(86 \mathrm{mmol} / \mathrm{mol})$, with very high insulin $(>1700 \mathrm{mU} / \mathrm{L})$ and C-peptide $(>4.5 \mathrm{ng} / \mathrm{mL})$ levels, accompanied by undetectable IGF-I $(<-25 \mathrm{ng} / \mathrm{mL})$ and IGFBP-3 $(<0.5 \mu \mathrm{g} / \mathrm{mL})$ concentrations.

An abdominal ultrasound demonstrated hyperechogenic kidneys. Echocardiography showed a small, but hypertrophic left ventricle. Ophthalmological examination and otolaryngeal status, including auditory brainstem response audiometry, was without pathological findings, except for mucous obstruction of the upper airways.

Based on previous publications of patients suffering from either type A insulin resistance or DS, who were successfully treated with rhIGF-I $[1,12,30]$, we decided to start a mecasermin trial. The parents' informed consent was obtained after they were given detailed information on the therapy and medication.

The initial treatment consisted of rhIGF-I application via BID injection. The initial dosage consisted of $2 \times 200 \mu \mathrm{g}$ mecasermin, which was escalated to a final dose of $2 \times 1 \mathrm{mg} /$ day, corresponding to a dosage of $0.5 \mathrm{mg} / \mathrm{kg}$ body weight per day over a period of one week. However, since we found no relevant effect on diurnal glucose control, and rather, an aggravation of fasting hypoglycemia during the night, we decided to test continuous subcutaneous mecasermin infusion using an insulin pump. Mecasermin was diluted with physiological $\mathrm{NaCl}$ infusion solution, with a final rhIGF-I dosage of $1.8 \mathrm{mg} /$ day (see Figure 1).

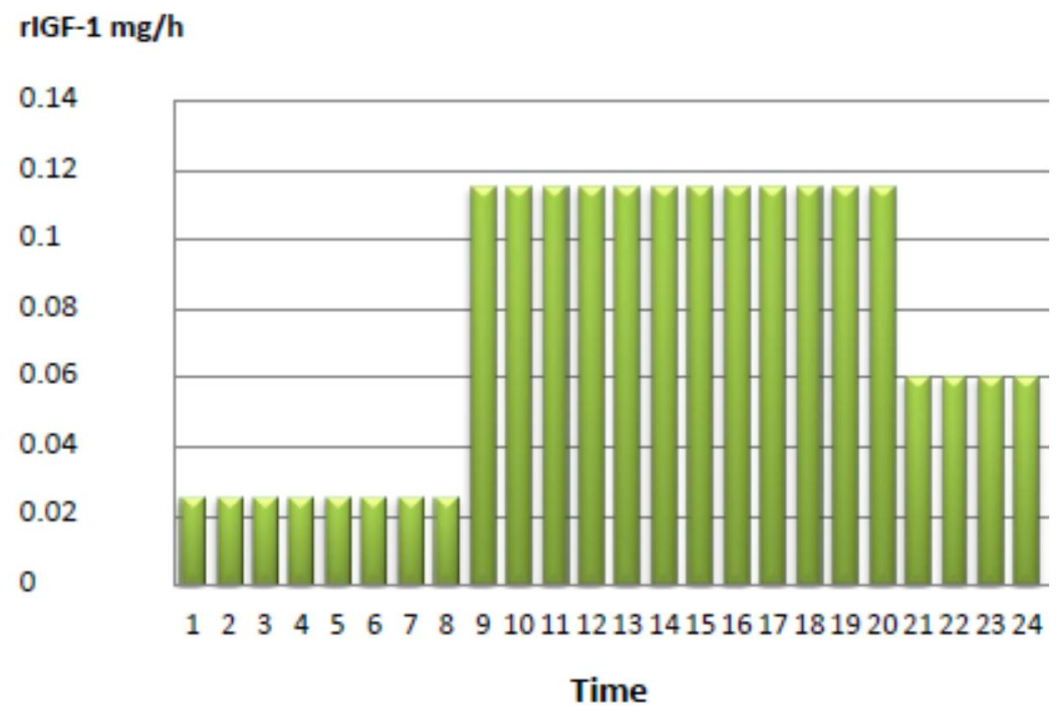

Figure 1. Mecasermin delivery in $\mathrm{mg} / \mathrm{h}$ via an insulin pump in the reported patient.

After discharge, the family travelled back to Libya. Because of the distance to the family's home country and the difficult political situation in Libya, it was not possible to see the patient and his parents more frequently than every four to six months. During these follow-up examinations anthropometry, clinical status, abdominal and thymus ultrasound, bone age, echocardiography, otolaryngeal and 
ophthalmological status as well as several biochemical analyses (IGF-I, IGFBP-3, glucose homeostasis, insulin level, $\mathrm{HbA1c}$, cholesterol, growth hormone, $\mathrm{TSH}$, $\mathrm{ft} 4$, prolactin, blood count, electrolytes, renal and liver parameters) were monitored. In between visits, we had regular email correspondence with the parents, and the child was seen by a diabetologist in his home country.

We saw the patient again at an age of 13 months. Even though the family was highly motivated to use the rhIGF-I infusion, intermittent therapy was not possible because the family could not get the medication in their home country due to logistical problems. Meanwhile the patient lost weight, now weighing $3300 \mathrm{~g}$. His $\mathrm{HbA} 1 \mathrm{c}$ was still $10 \%$. We reinitiated the therapy, and this time the family took the medication from Germany to Libya for the next 6 months. At an age of 18 months, after completion of six months of continuous subcutaneous rhIGF-I infusion via insulin pump, the patient presented again in our hospital. His weight was $5250 \mathrm{~g}$ (-5.65 SDS). His HbA1c had improved from 10.0 to $7.6 \%$. Blood glucose trends were more stable than they had been without mecasermin therapy (see Figure 2).

\section{a: before IGF-I infusion}

(12.5 months, HbA1c $10.0 \%$, weight $3.3 \mathrm{~kg}$ )

\section{b: after start of IGF-I infusion}

(18.5 months, HbA1c 7.6\%, weight $5.2 \mathrm{~kg}$ )

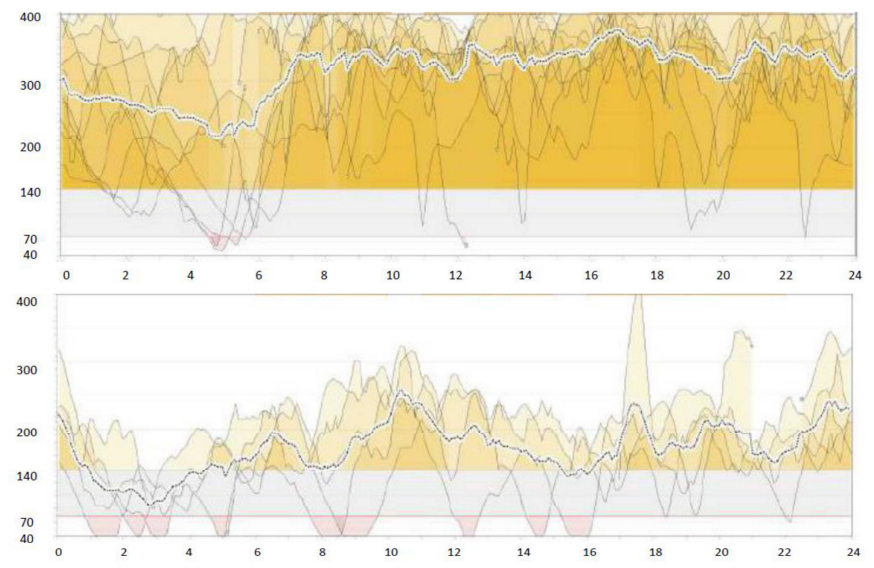

Figure 2. Glucose profile using a continuous glucose monitoring system (CGMS) before (a) and after (b) initiation of continuous subcutaneous mecasermin infusion via an insulin pump.

In addition, we saw a moderate improvement in motor function and muscular strength. The renal ultrasound, echocardiography and ophthalmological examination results were unchanged relative to those collected before treatment with mecasermin. The otolaryngeal examination revealed adenoid hypertrophy as a potential adverse event of rhIGF-I therapy, leading to an intermittent nocturnal oxygen requirement. Adenoidectomy and tympanic paracentesis were performed. Postoperatively, weaning from ventilation and extubation was complicated by rapid desaturation and hypoxia, requiring cardiopulmonary reanimation (CPR) and subsequent ventilation for several days. Following stabilization, the patient was discharged, and continued with continuous rhIGF-I infusion as described above. Unfortunately, four months after discharge at an age of 22 months the patient died during the course of a respiratory infection in a hospital in Libya.

\section{Overview of Current Knowledge on the Use of rhIGF-I in SIR}

\subsection{Clinical Picture of SIR}

As described above, INSR-related severe insulin resistance compromises a phenotypical continuum, with the most severe phenotype seen in DS (leprechaunism) and a milder phenotype in RMS [3], with type A insulin resistance being a relatively mild form of SIR. The INSR gene maps to the short arm of chromosome 19 and is composed of 22 exons [45].

DS and RMS are caused by autosomal recessive mutations of the INSR gene. There is a limited correlation between genotype and phenotype [45]. The most severe phenotypes result from mutations that markedly impair insulin binding. Mutations in the insulin receptor that retain residual insulin-binding are correlated with prolonged survival $[45,46]$. However, a definitive 
genotype-phenotype correlation for INSR defects is difficult to establish, primarily due to the rarity of these syndromes [46]. Dysmorphic features of DS and RMS resemble each other (see Table 1), but are less apparent in RMS. Some clinical aspects, like hirsutism or genital enlargement sometimes seem to appear later in RMS [3].

Children with DS present frequently with severe global developmental delay [8], which might be caused by recurrent severe hypoglycemic episodes [47]. Without intervention, death occurs within the first two years of life. Respiratory infections, hypoglycemia $[5,6]$ and cardiomyopathy $[7,8]$ seem to be the major causes of death [3]. Patients who were characterized as leprechaunism and showed long-term survival and normal psychomotor development [48] might have had benefit from early rhIGF-I therapy or should rather have been classified as a patient with RMS [3].

The manifestation of type A insulin resistance occurs commonly around puberty. Patients are normally not obese (in contrast to the majority of polycystic ovary syndrome (PCOS) subjects) and suffer from hyperandrogenism (PCOS in females, hirsutism, acne) and insulin resistance (diabetes, acanthosis nigricans). In subjects with type A insulin resistance, growth in infancy and childhood is normal. There is no intellectual impairment [12,49] (Table 1). Some cases can be attributed to a detectable heterozygous genetic defect in the INSR gene (most cases are autosomal-dominant, but autosomal-recessive cases have been reported as well).

Simpkin et al. [50] reported about 17 patients (eight with a complete dataset) with INSR mutations and a clinical diagnosis of DS or RMS. INSR dysfunction was associated with hypercalciuria and nephrocalcinosis, but no other consistent abnormality of renal function was noted. These results were in contrast to results in genetically modified mice, which showed elevated blood pressure and progressive diabetic nephropathy [51]. Differences between mice and men have also been observed for other aspects of the phenotype of insulin receptor deficiency [50]. INSR knockout mice die soon after birth because of ketoacidosis [52], whereas diabetic ketoacidosis does not seem to occur in human patients with Donohue syndrome [53], at least not in the first years of life [13]. Complete deletion of the insulin receptor gene is compatible with life in men [54].

To achieve the best possible treatment of children with DS and RMS, a close collaboration between several subspecialties is required. Paediatric endocrinologists are typically in charge of assessing glycemic control and respective treatment regimens, paediatric cardiologists monitor hypertrophic cardiomyopathy, and neuropaediatricians are involved in monitoring neurological development and the initiation of supportive care. A screening protocol regarding the occurrence of nephrocalcinosis and/or impaired renal function as well as liver function should be initiated. Adequate nutrition and caloric intake are of paramount importance to improve blood sugar concentrations, weight gain and growth. Routine ultrasound examinations should be performed to control the morphology of ovaries in girls as well as the morphology of the kidneys, liver and spleen in both sexes [3]. In subjects in whom rhIGF-I treatment is started, repetitive fundoscopy and otolaryngeal examinations should be scheduled. Because of dental crowding, orthodontic treatment could be necessary $[55,56]$.

Table 1. Characteristic clinical features of subjects with Donohue syndrome (DS), Rabson-Mendenhall Syndrome (RMS) and Type A Insulin Resistance (Type A IR) [3,5-8,10,49,50,56-63].

\begin{tabular}{clll}
\hline \multicolumn{1}{c}{ DS } & \multicolumn{1}{c}{ RMS } & \multicolumn{1}{c}{ Type A Insulin Resistance } \\
\hline Molecular genetics & $\begin{array}{l}\text { Homozygous mutation in the } \\
\text { insulin receptor (INSR) gene }\end{array}$ & $\begin{array}{l}\text { Compound heterozygous mutation } \\
\text { in INSR gene } \\
\text { receptor gene insulin } \\
\text { (autosomal-dominant or } \\
\text { autosomal-recessive) }\end{array}$ & Normal phenotype \\
\hline \multirow{2}{*}{ Face } & $\begin{array}{l}\text { Proptosis } \\
\text { Infraorbital folds } \\
\text { Large, posteriorly rotated ears } \\
\text { Thick lips } \\
\text { Gingival hyperplasia } \\
\text { Broad nasal tip }\end{array}$ & $\begin{array}{l}\text { Resembling DS } \\
\text { or milder phenotype }\end{array}$ & \\
\hline
\end{tabular}


Table 1. Cont.

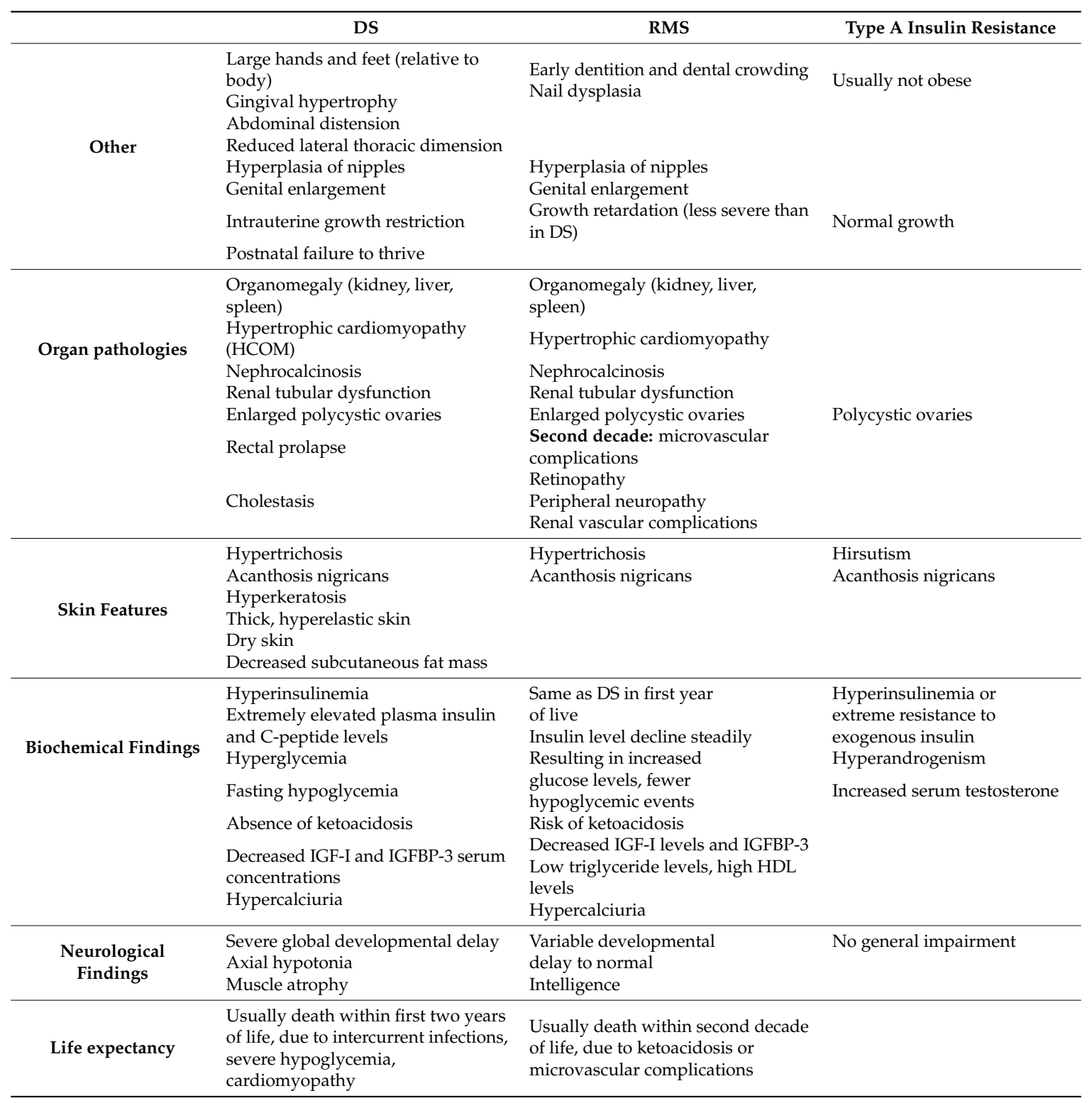

\subsection{Treatment Options in SIR Other Than rhIGF-I}

Hyperglycaemia in patients with insulin receptor mutations is extremely difficult to treat $[12,18]$, and patients are at risk for early morbidity and mortality from the microvascular complications of diabetes [18,57]. In particular, DS has a poor prognosis with only few therapeutic options being available. In subjects with type A insulin resistance or RMS, the use of insulin sensitizing drugs, such as metformin or rosiglitazone, should be first-line therapy. However, previous reports have indicated that a positive therapeutic impact is only be observed in a fraction of patients and that, over time, the effect of these drugs seems to diminish [64]. Frequently, affected patients require multidrug therapy $[64,65]$.

Moreira et al. [65] reported a successful reduction of HbA1c in a patient with RMS using a combination of nutritional counseling, physical activity, and the following medications: metformin, pioglitazone, vildagliptin and acarbose. The authors mentioned that the use of dipeptidylpeptidase-4 inhibitors might be a promising new approach for patients with RMS.

In cases for whom insulin therapy is initiated, patients require very high insulin doses and therefore, in most cases, U-500 insulin is used for treatment $[12,14,66,67]$. In patients treated with U-500 
insulin, continuous subcutaneous insulin infusion (CSII) is a viable option [12]. While common therapeutic targets may not be achievable in SIR patients, large doses of insulin can improve hyperglycemia, catabolic state and weight loss and reduce the risk of microvascular complications [14]. Metreleptin has been reported to improve glucose metabolism in subjects with genetic lipodystrophic syndromes, and it has been reported to be a potential therapeutic option in patients with RMS [17,18]. In that regard, Brown et al. [18] treated five patients with RMS with metreleptin and were able to show a decrease in $\mathrm{HbA} 1 \mathrm{c}$, from $11.4 \%$ at baseline to $9.3 \%$ after six months and $9.7 \%$ after 12 months of metreleptin treatment. However, the authors also reported that these beneficial effects of metreleptin on $\mathrm{HbA1c}$ concentration appeared to wane over time, and metreleptin treatment, with or without insulin, in the long-term was insufficient to achieve targeted $\mathrm{HbA1c}$ levels. There has been a single observation in a patient with type A insulin resistance available which reported a remarkable improvement of glycemic control after starting a suppressive dose of levothyroxine [68]. Since the thyroid hormone is an activator of brown adipose tissue and because positron emission tomography (PET) showed the presence of brown adipose tissue in this patient, the activation of brown adipose tissue might be a new therapeutic target of SIR [69]. In DS, metformin and insulin treatment usually do not improve glycaemic control $[12,57]$. To the best of our knowledge, successful metreleptin treatment has not been reported in DS yet. Frequent or continuous gastric feeding seems to be efficient for preventing fasting hypoglycaemia in patients with DS [12]. Table 2 summarizes the different treatment options in patients with SIR.

Table 2. Therapeutic efficiency of available treatment options in SIR.

\begin{tabular}{|c|c|c|c|}
\hline Treatment Option & DS & RMS & Type A IR \\
\hline $\begin{array}{l}\text { Nutrition: } \\
\text { Frequent/continuous } \\
\text { feeding }\end{array}$ & $\begin{array}{l}\text { Prevents fasting } \\
\text { hypoglycaemia }\end{array}$ & Prevents fasting hypoglycaemia & \\
\hline $\begin{array}{l}\text { Avoidance of high } \\
\text { carbohydrate diet }\end{array}$ & & Useful & Useful \\
\hline Insulin sensitizer & No effect & $\begin{array}{l}\text { Early usage recommended. } \\
\text { Improvement of } \\
\text { hyperglycaemia }\end{array}$ & $\begin{array}{l}\text { Early usage recommended. } \\
\text { Improvement of } \\
\text { hyperglycaemia }\end{array}$ \\
\hline High dose insulin & No effect & $\begin{array}{l}\text { Improvement of } \\
\text { hyperglycaemia, catabolic state, } \\
\text { weight loss and microvascular } \\
\text { complications [14] }\end{array}$ & $\begin{array}{l}\text { Improvement of } \\
\text { hyperglycaemia, catabolic state } \\
\text { and microvascular } \\
\text { complications [14] }\end{array}$ \\
\hline Metreleptin & No assessment available & Improvement of $\mathrm{HbA1c}$ [18] & $\begin{array}{l}\text { No study with type A IR } \\
\text { patients available. }\end{array}$ \\
\hline Mecasermin (rhIGF-I) & See Table 3 & See Table 3 & See Table 3 \\
\hline
\end{tabular}

\subsection{Use of rhIGF-I in Insulin Receptor-Related Severe Insulin Resistance Syndromes}

Because of its previously reported effect on glucose homeostasis, rhIGF-I has been postulated as a potential therapeutic option in SIR syndromes. The IGF-I gene is a major target of growth hormone $(\mathrm{GH})$ and an important mediator of GH-stimulated growth, but exerts different effects on carbohydrate, lipid and protein metabolism compared to GH. IGF-I stimulates a reduction in blood glucose and circulating insulin levels and therefore, can cause hypoglycaemia [70]. This effect is in part mediated through IGF-I's structural similarity with insulin and its affinity to the insulin and IGF-I receptors, which share common post-receptor signaling pathways $[19,20]$. In vitro studies using adenoviral IGF-I gene transfer into $B$-cells have shown the promotion of $\beta$-cell survival and proliferation [71]. Furthermore, islet cell exposure towards IGF-I seems to sustain or increase insulin synthesis [72]. Therefore, an increase in the circulating insulin concentration under conditions where a residual insulin effect is maintained, either through insulin/IGF-hybrid receptors or through mutated insulin receptors with residual IR function, might lead to an improvement in glucose homeostasis. In SIR, the effects of rhIGF-I on glucose homeostasis are thought to occur mainly through increased 
glucose uptake into peripheral tissues (e.g., muscle) and a reduction in hepatic glucose production (see Figure 3).

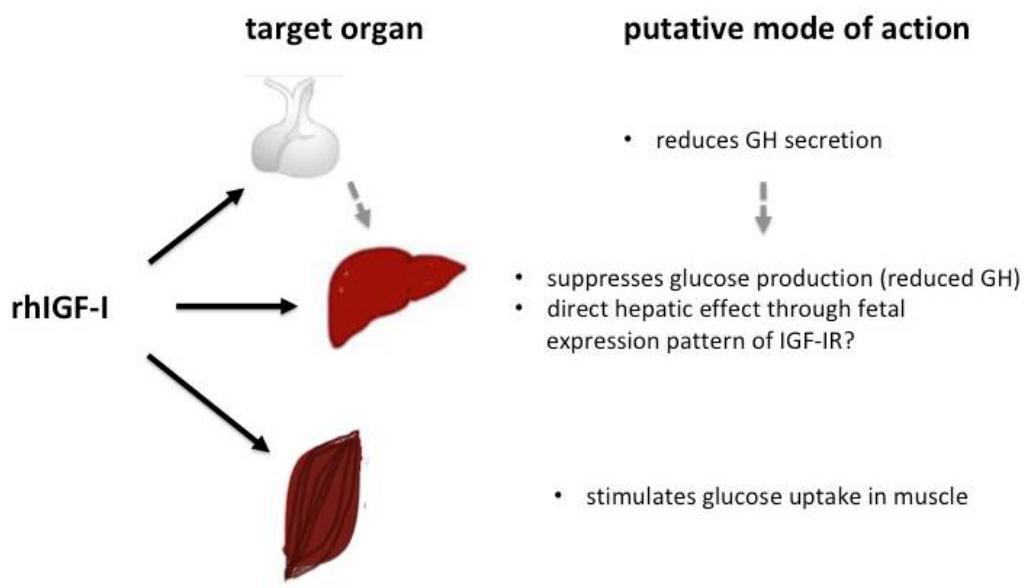

Figure 3. Putative effects of rhIGF-I on glucose homeostasis.

The first reports of rhIGF-I use in patients with SIR were published in the 1990s. Single-dose intravenous administration of rhIGF-I with a dosage of $100 \mu \mathrm{g} / \mathrm{kg} /$ day was associated with declines in blood glucose, plasma insulin, C-peptide and GH concentrations [23,24]. These initial trials were followed by trials using subcutaneous application of rhIGF-I [22,25-28,63,73]. Kuzuya [73] first described the usage of rhIGF-I over a period of several months (up to 16 months) as leading to a decrease in $\mathrm{HbA1c}$ concentration in patients with SIR. Most publications are either single case reports or include only few (up to six) patients with an SIR syndrome, with pronounced differences in clinical phenotypes (from DS over RMS to Type A IR). Therefore, a direct comparison of the respective treatment effects between the mentioned case reports/small studies is not possible. Table 3 gives a summary of different rhIGF-I trials reporting either short or long-term effects of rhIGF-I in SIR, including trials with no apparent benefit of rhIGF-I in the treatment of patients with SIR syndromes [74,75]. Backeljauw [75] and coworkers treated two infants classified as DS with intravenous rhIGF-I over a period of 66 and $62 \mathrm{~h}$, respectively, and could not see any apparent glucose lowering or a decrease in insulin concentration. A potential explanation for this might be that the effect of rhIGF-I on glucose metabolism in SIR is just as heterogenous as the syndrome itself [74]. In addition to SIR, there are some single case reports regarding successful long-term use of rhIGF-I in patients with leprechaunism $[29,31]$. In the patient reported above, we were not able to see an improvement of glucose homeostasis by administration of BID mecasermin application. However, we cannot exclude that a higher dosage or more prolonged trial of mecasermin application might have led to a more favourable response [29,31,32] (see also Table 3). Still, the observation of more satisfactory results on blood glucose homeostasis using a continuous application of rhIGF-I via an insulin pump is in accordance with other reports $[30,76]$. The half-life of insulin-like growth factor I seems to be decreased in patients with insulin receptor defects, which, in part, can be explained by drastically decreased or absent IGF binding protein-3 concentrations. In order to analyse why rhIGF-I is not consistently effective in patients with Rabson-Mendenhall syndrome, Longo et al. [63] measured IGF-I concentrations in a patient after subcutaneous injections. The IGF-I half-life was dramatically reduced (1.3-3 h) compared to the normal range of $17-22 \mathrm{~h}$ in healthy subjects. This might partly explain why the use of "moderate" mecasermin dosages of $0.5 \mathrm{mg} / \mathrm{kg} /$ day, or even less via continuous subcutaneous infusion, can lead to results that are as satisfactory as those from the use of a very high dose of rhIGF-I through a single injection (for example $1.6 \mathrm{mg} / \mathrm{kg} /$ day [29]). 
Table 3. Treatment trials with rhIGF-I in patients with severe INSR-related insulin resistance syndromes (SIR).

\begin{tabular}{|c|c|c|c|c|}
\hline Author & $\begin{array}{c}\text { Treatment Duration of } \\
\text { rhIGF-I }\end{array}$ & SIR Syndrome (n) & Dosage & Efficacy and Safety \\
\hline Quin et al., 1990 [23] & $\begin{array}{l}\text { Short term } \\
1 \text { dose }\end{array}$ & RMS (1 patient) & $100 \mu \mathrm{g} / \mathrm{kg} /$ day i.v. & $\begin{array}{l}\text { Blood glucose, plasma insulin, } \\
\text { C-Peptide and growth } \\
\text { hormone (GH) declined }\end{array}$ \\
\hline Schoenle et al., 1991 [24] & $\begin{array}{l}\text { Short term } \\
2 \text { doses }\end{array}$ & Type A IR (3 patients) & $100 \mu \mathrm{g} / \mathrm{kg} /$ day i.v. & $\begin{array}{l}\text { Blood glucose, plasma insulin } \\
\text { and C-peptide decreased }\end{array}$ \\
\hline Hussain et al., 1993 [22] & $\begin{array}{l}\text { Short term } \\
4 \text { days, BID }\end{array}$ & Type A IR (1 patient) & $160 \mu \mathrm{g} / \mathrm{kg} /$ day s.c. & $\begin{array}{l}\text { Lowering of fasting and } \\
\text { postprandial blood glucose, } \\
\text { insulin and C-peptide levels }\end{array}$ \\
\hline Kuzuya et al., 1993 [73] & Up to 16 months & $\begin{array}{l}\text { Type A IR (6 patients) } \\
\text { DS ( } 2 \text { patients) } \\
\text { Congenital lipodystrophy } \\
\text { ( } 2 \text { patients) } \\
\text { Other (1 patient) }\end{array}$ & 100 to $400 \mu \mathrm{g} / \mathrm{kg} /$ day & $\begin{array}{l}\text { Lowering of fasting and } \\
\text { postprandial glucose. } \\
\text { Decrease of HbA1c and } \\
\text { fructosamine }\end{array}$ \\
\hline Morrow et al., 1994 [27] & 3-4 weeks & $\begin{array}{l}\text { Type A without insulin } \\
\text { receptor mutations ( } 2 \text { patients) }\end{array}$ & $100 \mu \mathrm{g}$ s.c. & $\begin{array}{l}\text { Reduction of blood glucose } \\
\text { level, enhancement of insulin } \\
\text { sensitivity }\end{array}$ \\
\hline Backeljauw, 1994 [75] & $66 \mathrm{~h}$ and $62 \mathrm{~h}$ & DS (2 patients) & $\begin{array}{l}\text { Up to } 110 \mu \mathrm{g} / \mathrm{kg} / \mathrm{h} \text { and } \\
40 \mu \mathrm{g} / \mathrm{kg} / \mathrm{h} \text { i.v. }\end{array}$ & $\begin{array}{l}\text { No apparent glucose lowering } \\
\text { effect, decrease in insulin } \\
\text { concentration }\end{array}$ \\
\hline Zenobi, 1994 [25] & 5 days & Type A IR (2 patients) & $150 \mu \mathrm{g} / \mathrm{kg} 2$ x/day s.c. & $\begin{array}{l}\text { Decrease of fasting blood } \\
\text { glucose. Decrease in fasting } \\
\text { insulin and C-peptide by } 65 \%\end{array}$ \\
\hline Longo et al., 1994 [63] & 16 months & RMS (1 patient) & $\begin{array}{l}\text { Up to } 100 \mu \mathrm{g} / \mathrm{kg} / \text { day } \\
\text { s.c. }\end{array}$ & $\begin{array}{l}\text { No significant effect on } \\
\text { glycaemic control and growth }\end{array}$ \\
\hline Nakashima et al., 1995 [28] & 9 months & Type A IR (1 patient) & $0.08-0.2 \mathrm{mg} / \mathrm{kg} /$ day s.c. & $\begin{array}{l}\text { Decrease in blood glucose } \\
\text { level, free fatty acid } \\
\text { concentration, HbA1c; } \\
\text { enhanced insulin sensitivity, } \\
\text { improvement of acanthosis } \\
\text { nigricans }\end{array}$ \\
\hline \multirow[t]{2}{*}{ Vestergaard et al., 1997 [26] } & $\begin{array}{l}2 \text { weeks high dose } \\
\text { rhIGF-I }\end{array}$ & SIR (4 patients) & $60 \mu \mathrm{g} / \mathrm{kg} 2 \mathrm{x} /$ day s.c. & $\begin{array}{l}\text { Reduction of fasting blood } \\
\text { glucose and insulin }\end{array}$ \\
\hline & $\begin{array}{l}10 \text { weeks low dose } \\
\text { rhIGF-I }\end{array}$ & SIR (3 patients) & $40 \mu \mathrm{g} / \mathrm{kg} /$ day s.c. & \\
\hline Takahashi et al., 1997 [32] & 6 months & Leprechaunism -1 patient & $\begin{array}{l}100 \mu \mathrm{g} / \mathrm{kg} / \text { day up to } \\
1000 \mu \mathrm{g} / \mathrm{kg} / \text { day }\end{array}$ & $\begin{array}{l}\text { Fasting blood glucose, insulin, } \\
\text { HbA1c, body weight and } \\
\text { development improved }\end{array}$ \\
\hline Nakae et al., 1998 [29] & 6 years and 10 months & $\begin{array}{l}\text { DS (?) or RMS (?) (1 patient at } \\
\text { different time points) }\end{array}$ & Up to $1.6 \mathrm{mg} / \mathrm{kg} /$ day & $\begin{array}{l}\text { Maintained growth rate, } \\
\text { HbA1c near normal range }\end{array}$ \\
\hline Kitamei et al., 2004 [78] & & & $\begin{array}{l}\text { Intermittent and } \\
\text { continuous s.c injection }\end{array}$ & $\begin{array}{l}\text { Adult height was } 143 \mathrm{~cm} \\
\text { ( }-2.7 \text { SDS for Japanese girls) }\end{array}$ \\
\hline Jo et al., 2013 [77] & $\begin{array}{l}\text { Withdrawl of rhIGF-I } \\
\text { treatment at } 18 \text { years, } \\
\text { due to diabetic } \\
\text { ketoacidosis and start of } \\
\text { high dose insulin }\end{array}$ & & & $\begin{array}{l}\text { Recurrent episodes of } \\
\text { ketoacidosis. HbA1c up to } \\
12-13 \%\end{array}$ \\
\hline Regan et al., 2010 [79] & 16 weeks & Type A IR (5 patients) & $\begin{array}{l}0.5-2 \mathrm{mg} / \mathrm{kg} \\
\text { rhIGF-I/rhIGFBP-3 }\end{array}$ & $\begin{array}{l}\text { HbA1c improvement, } \\
\text { reduction of acanthosis } \\
\text { nigricans }\end{array}$ \\
\hline Weber et al., 2014 [30] & $\begin{array}{l}16 \text { months (from } 19 \\
\text { months up to } 35 \\
\text { months-death of the } \\
\text { patient) }\end{array}$ & DS (1 patient) & $\begin{array}{l}\text { BID } 80 \text { up to } 640 \\
\mu \mathrm{g} / \mathrm{kg} / \text { day s.c.; } \\
\text { At } 30 \text { months: } \\
\text { continuous s.c. infusion } \\
\text { via insulin pump: } \\
800-1200 \mu \mathrm{g} / \mathrm{kg} / \text { day }\end{array}$ & $\begin{array}{l}\text { HbA1c improvement from } 9.5 \\
\text { to } 7.7 \% \text {, rebound to } 9.8 \% \\
\text { Improvement of HbA1c from } \\
9.8 \text { to } 8.8 \% \text {, } \\
\text { Moderate weight gain }\end{array}$ \\
\hline De Kerdanet et al., 2015 [48] & $\begin{array}{l}8.7 \text { years; } \\
2 \text { years }\end{array}$ & DS (1 patient) & $\begin{array}{l}\text { IGF-I/IGFBP3 } \\
\text { combination, subsequ. } \\
\text { IGF-I alone } 50 \\
\mu \mathrm{g} / \mathrm{kg} / \text { day s.c. }\end{array}$ & $\begin{array}{l}\text { Decrease in mean glycaemia } \\
\text { with large variation. } \\
\text { Improvement of growth. }\end{array}$ \\
\hline Carmody et al., 2016 [31] & 5 years & RMS (1 patient) & $\begin{array}{l}\text { rhIGF-I up to } 1.72 \mathrm{U} / \mathrm{kg} \\
2 \mathrm{x} / \text { day s.c. }+ \text { metformin }\end{array}$ & $\begin{array}{l}\text { Decrease in insulin, homa } \\
\text { index and HbA1c. Growth } \\
\text { maintained within target } \\
\text { height range. }\end{array}$ \\
\hline
\end{tabular}

In addition to pharmacokinetic influences on treatment success, functional analyses of the INSR gene can aid in the prediction of the severity of an INSR mutation and its associated disease phenotype [76] and thereby, might aid in predicting the effectiveness of rhIGF-I treatment. Furthermore, the timing of treatment has been associated with the treatment response. Early treatment with rhIGF-I 
has been reported to increase the lifespan of patients with DS or Rabson-Mendenhall syndrome [29,76]. However, the effectiveness of rhIGF-I therapy seems to decrease with progression of the disease [77].

Mecasermin use has been associated with a number of adverse effects, in particular hypoglycaemia, pain at injection side and lymphoid tissue hypertrophy. Lymphoid tissue hypertrophy has been described in about $25 \%$ of all patients who were treated with mecasermin and is associated with the requirement of surgery in $>10 \%$ of patients $[20,80]$ (see Table 4 ).

Table 4. Adverse effects of mecasermin treatment in conditions other than SIR and in patients with SIR.

\begin{tabular}{|c|c|c|}
\hline Adverse Effects & Indication Other than SIR [20] & SIR \\
\hline Hypoglycaemia & $50-86 \%$ & +++ \\
\hline Mild pain/erythema at injection side & +++ & $++[27,79]$ \\
\hline Paresthesia and painful toes & & $++[28]$ \\
\hline Lipohypertrophy & $1 / 3$ & \\
\hline (Asymptomatic) tachycardia & +++ & + \\
\hline Parotid swelling & + & \\
\hline Facial nerve palsy & + & \\
\hline Retinopathy/worsening of retinopathy & + & $\begin{array}{l}+[1,20,28,77-79] \\
{[77,78]^{\#} \text { (patient's age } 12 \text { years) }}\end{array}$ \\
\hline Muscle pain * & + & $+[1,20]$ \\
\hline Fluid retention/edema* & + & $+[1,20]$ \\
\hline Arthritis * & + & $+[20]$ \\
\hline $\begin{array}{l}\text { Benign intracranial hypertension } \\
\text { /papilledema }\end{array}$ & $5 \%$ & $+[1]$ \\
\hline $\begin{array}{l}\text { Lymphoid tissue hypertrophy: tonsillar } \\
\text { hypertrophy } \\
\text { Adenoidal hypertrophy }\end{array}$ & $\begin{array}{l}25 \% \text { ( }>10 \% \text { require surgical } \\
\text { intervention) }\end{array}$ & $\begin{array}{l}\left.+[29]{ }^{\#} \text { (patient's age } 3 \text { years }\right) \\
+[76]\end{array}$ \\
\hline Thymic hypertrophy & $35 \%$ (X-ray) & \\
\hline Mastitis & & ? [77] ${ }^{\#}$ (age 16 years) \\
\hline Endometrial cancer & & $+[77]^{\#}$ (age 24 years) \\
\hline
\end{tabular}

In our case report, after six months of mecasermin treatment, our patient underwent surgery for probably treatment-related development of adenoid hypertrophy. Nakae, Kitamei and Jo et al. $[29,77,78]$ reported information about one patient at different time points over the clinical course. The patient was treated with rhIGF-I from an age of six months until 18 years, with further follow-up to an age of 24 years. During this time course, the patient developed several symptoms, which could be interpreted as adverse effects of rhIGF-I therapy, although disease-inherent development of the complications cannot be ruled out: tonsillar hypertrophy (at three years of age), retinal neovascularization (at 12 years of age), mastitis (at 16 years) and endometrial cancer (at 24 years of age). In another patient with DS [30], the development of a granulosa cell tumor was reported, but its relationship to concomitant rhIGF-I therapy remains unclear, since a comparable tumour developed in a girl with leprechaunism who was not treated with rhIGF-I [81]. Other authors did not observe any side effects of rhIGF-I therapy in patients with SIR over a period of five [31] or 10 years [48]. Table 4 summarizes the possible adverse effects of mecasermin therapy in general and the reported side effects of its use in SIR.

In addition to the putative adverse effects depicted in Table 4, children with DS seem to have an increased risk during general anaesthesia [49]. The increase in risk might be related to the presence of restrictive lung disease, abdominal distension and difficult airway conditions. Kirkwood presented a case series of five patients with DS who underwent 12 treatments with general anaesthesia. 
Two anaesthesia treatments (in two patients) were complicated by cardiac arrest, secondary to difficult manual ventilation, intubation, and hypoxia and required CPR, resembling our case report.

\section{Conclusions}

The treatment of SIR syndromes is challenging. Even though there are some treatment options available for patients with a Type A insulin resistance phenotype- the mildest form of the INSR-related SIR syndromes-general treatment goals, e.g., long-term normalization of $\mathrm{HbA1c}$ cannot be achieved in most cases. The effects of all medications mentioned above (insulin sensitizer, insulin, metreleptin, mecasermin) seem to diminish over time.

The optimal timing, application form and dosage of rhIGF-I still remain unclear, but this seems to be the most effective type of therapy in patients with DS so far. Continuous application via pump might be advantageous compared to single injections.

Further treatment options are clearly needed to improve the quality of life and life expectancy of patients with SIR syndromes. Careful consideration of the therapeutic benefits and the burden of the disease is warranted.

Author Contributions: Michaela Plamper and Joachim Woelfle conceived and designed the study protocol and discussed treatment strategies. Michaela Plamper, Felix Schreiner, Bettina Gohlke and Joachim Woelfle contributed specific parts of the paper. All authors approved the submitted version.

Conflicts of Interest: The authors declare no conflict of interest.

\section{References}

1. McDonald, A.; Williams, R.; Regan, F.M.; Semple, R.K.; Dunger, D.B. IGF-I treatment of insulin resistance. Eur. J. Endocrinol. 2007, 157, 51-56. [CrossRef] [PubMed]

2. Parker, V.E.R.; Semple, R.K. Genetic Forms of Severe Insulin Resistance: What Endocrinologists Should Know. Eur. J. Endocrinol. 2013, 169, 71-80. [CrossRef] [PubMed]

3. Ben Harouch, S.; Falik Zaccai, T.C.; Klar, A. INSR-Related Severe Syndromic Insulin Resistance. In GeneReviews $^{\circledR}$ [Internet]; Adam, M.P., Ardinger, H.H., Pagon, R.A., Wallace, S.E., Bean, L.J.H., Stephens, K., Amemiya, A., Eds.; University of Washington: Seattle, WA, USA, 1993-2018; Available online: http:/ /www.ncbi.nlm.nih.gov/books/NBK476444/ (accessed on 25 January 2018).

4. Donohue, W.L.; Uchida, I. Leprechaunism: A euphemism for a rare familial disorder. J. Pediatr. 1954, 455, 505-519. [CrossRef]

5. Elders, M.J.; Schedewie, H.K.; Olefsky, J.; Givens, B.; Char, F.; Bier, D.M.; Baldwin, D.; Fiser, R.H.; Seyedabadi, S.; Rubenstein, A. Endocrine-metabolic relationships in patients with leprechaunism. J. Natl. Med. Assoc. 1982, 74, 1195-1210. [PubMed]

6. De Bock, M.; Hayes, I.; Semple, R. Donohue syndrome. J. Clin. Endocrinol. Metab. 2012, 97, 1416-1417. [CrossRef] [PubMed]

7. Grasso, V.; Colombo, C.; Favalli, V.; Galderisi, A.; Rabbone, I.; Gombos, S.; Bonora, E.; Massa, O.; Meschi, F.; Cerutti, F.; et al. Six cases with severe insulin resistance (SIR) associated with mutations of insulin receptor: Is a Bartter-like syndrome a feature of congenital SIR? Acta Diabetol. 2013, 50, 951-957. [CrossRef] [PubMed]

8. Falik Zaccai, T.C.; Kalfon, L.; Klar, A.; Ben Elisha, M.; Hurvitz, H.; Weingarten, G.; Chechik, E.; Fleisher Sheffer, V.; Haj Yahya, R.; Meidan, G.; et al. Two novel mutations identified in familial cases with Donohue syndrome. Mol. Genet. Genom. Med. 2014, 2, 64-72. [CrossRef] [PubMed]

9. Desbois-Mouthon, C.; Girodon, E.; Ghanem, N.; Caron, M.; Pennerath, A.; Conteville, P.; Magre, J.; Besmond, C.; Goossens, M.; Capeau, J.; et al. Molecular analysis of the insulin receptor gene for prenatal diagnosis of leprechaunism in two families. Prenat. Diagn. 1997, 17, 657-663. [CrossRef]

10. Rabson, S.M.; Mendenhall, E.N. Familial hypertrophy of pineal body, hyperplasia of adrenal cortex and diabetes mellitus. Am. J. Clin. Pathol. 1956, 26, 283-290. [CrossRef] [PubMed]

11. Longo, N.; Wang, Y.; Pasquali, M. Progressive decline in insulin levels in Rabson-Mendenhall syndrome. J. Clin. Endocrinol. Metab. 1999, 84, 2623-2629. [CrossRef] [PubMed]

12. Semple, R.; Williams, R.; Dunger, D.B. What is the best management strategy for patients with severe insulin resistance? Clin. Endocrinol. 2010, 73, 286-290. [CrossRef] [PubMed] 
13. Semple, R.K.; Savage, D.B.; Cochran, E.K.; Gorden, P.; O'Rahilly, S. Genetic syndromes of severe insulin resistance. Endocr. Rev. 2011, 32, 498-514. [CrossRef] [PubMed]

14. Cochran, E.; Musso, C.; Gorden, P. The use of U-500 in patients with extreme insulin resistance. Diabetes Care 2005, 28, 1240-1244. [CrossRef] [PubMed]

15. Huggard, D.; Stack, T.; Satas, S.; Gorman, C.O. Donohue syndrome and use of continuous subcutaneous insulin pump therapy. BMJ Case Rep. 2015, 27, 2015. [CrossRef] [PubMed]

16. Atabek, M.E.; Pirgon, O. Some effect of metformin on insulin resistance in an infant with leprechaunism. J. Pediatr. Endocrinol. Metab. 2006, 19, 1257-1261. [CrossRef] [PubMed]

17. Cochran, E.; Young, J.R.; Sebring, N.; DePaoli, A.; Oral, E.A.; Gorden, P. Efficacy of recombinant methionyl human leptin therapy for the extreme insulin resistance of the Rabson-Mendenhall syndrome. J. Clin. Endocrinol. Metab. 2004, 89, 1548-1554. [CrossRef] [PubMed]

18. Brown, R.J.; Cochran, E.; Gorden, P. Metreleptin improves blood glucose in patients with insulin receptor mutations. J. Clin. Endocinol. Metab. 2013, 98, E1749-E1756. [CrossRef] [PubMed]

19. Ullrich, A.; Gray, A.; Tam, A.W.; Yanf-Feng, T.; Tsubokawa, M.; Collin, C.; Henzel, W.; Le Bon, T.; Kathuria, S.; Chen, E. Insulin-like growth factor I receptor primary structure: Comparison with insulin receptor suggests structural determinants that define functional specifity. EMBO J. 1986, 5, 2503-2512. [PubMed]

20. Rosenbloom, A.L. Mecasermin (recombinant human insulin-like growth factor I). Adv. Ther. 2009, 26, 40-54. [CrossRef] [PubMed]

21. Williams, R.M.; McDonald, A.; O'Savage, M.; Dunger, D.B. Mecasermin rinfabate: rhIGF-I/rhIGFBP-3 complex: iPLEX. Expert Opin. Drug Metab. Toxicol. 2008, 4, 311-324. [CrossRef] [PubMed]

22. Hussain, M.A.; Froesch, E.R. Treatment of type A insulin resistance with insulin-like growth factor-I. Lancet 1993, 3418859, 1536-1537. [CrossRef]

23. Quin, J.D.; Fisher, B.M.; Paterson, K.R.; Inoue, A.; Beastall, G.H.; MacCuish, A.C. Acute response to recombinant insulin-like growth factor I in a patient with Mendenhall's syndrome. N. Engl. J. Med. 1990, 323, 1425-1426. [PubMed]

24. Schoenle, E.J.; Zenobi, P.D.; Torresani, T.; Werder, E.A.; Zachmann, M.; Froesch, E.R. Recombinant human insulin-like growth factor I (rhIGF I) reduces hyperglycaemia in patients with extreme insulin resistance. Diabetologia 1991, 34, 675-679. [CrossRef] [PubMed]

25. Zenobi, P.D.; Glatz, Y.; Keller, A.; Graf, S.; Jaeggi-Groisman, S.E.; Riesen, W.F.; Schoenle, E.J.; Froesch, E.R. Beneficial metabolic effects of insulin-like growth factor I in patients with severe insulin-resistant diabetes type A. Eur. J. Endocrinol. 1994, 131, 251-257. [CrossRef] [PubMed]

26. Vestergaard, H.; Rossen, M.; Urhammer, S.A.; Müller, J.; Pedersen, O. Short- and long-term metabolic effects of recombinant human IGF-I treatment in patients with severe insulin resistance and diabetes mellitus. Eur. J. Endocrinol. 1997, 136, 475-482. [CrossRef] [PubMed]

27. Morrow, L.A.; O’Brien, M.B.; Moller, D.E.; Flier, J.S.; Moses, A.C. Recombinant human insulin-like growth factor-I therapy improves glycemic control and insulin action in the type A syndrome of severe insulin resistance. J. Clin. Endocrinol. Metab. 1994, 79, 205-210. [PubMed]

28. Nakashima, N.; Umeda, F.; Yanase, T.; Nawata, H. Insulin resistance associated with substitution of histidine for arginine 252 in the alpha-subunit of the human insulin receptor: Trial of insulin-like growth factor I injection therapy to enhance insulin sensitivity. J. Clin. Endocrinol. Metab. 1995, 80, 3662-3667. [PubMed]

29. Nakae, J.; Kato, M.; Murashita, M.; Shinohara, N.; Tajima, T.; Fujieda, K. Long-term effect of recombinant human insulin-like growth factor I on metabolic and growth control in a patient with leprechaunism. JCEM 1998, 83, 542-549. [CrossRef] [PubMed]

30. Weber, D.; Stanescu, D.; Semple, R.; Holland, C.; Magge, S.N. Continuous, subcutaneous IGF-I therapy via insulin pump in patient with Donohue Syndrome. J. Pediatr. Endocrinol. Metab. 2014, 27, 1237-1241. [CrossRef] [PubMed]

31. Carmody, D.; Ladsaria, S.S.; Buikema, R.K.; Semple, R.K.; Greeley, S.A. Case Report: Successful rhIGF1 treatment for over 5 years in a patient with severe insulin resistance due to homozygous insulin receptor mutation. Diabet. Med. 2016, 33, e8-e12. [CrossRef] [PubMed]

32. Takahashi, Y.; Kadowaki, H.; Momomura, K.; Fukushima, Y.; Orban, T.; Okai, T.; Taketani, Y.; Akanuma, Y.; Yazaki, Y.; Kadowaki, T. A homozygous kinase-defective mutation in the insulin receptor gene in a patient with leprechaunism. Diabetologia 1997, 40, 412-420. [CrossRef] [PubMed] 
33. Grosse, G.; Hilger, A.; Ludwig, M.; Reutter, H.; Lorenzen, F.; Even, G.; Holterhus, P.M.; Woelfle, J.; German GHI Study Group. Targeted Resequencing of Putative Growth-Related Genes Using Whole Exome Sequencing in Patients with Severe Primary IGF-I Deficiency. Horm. Res. Paediatr. 2017, 88, 408-417. [CrossRef] [PubMed]

34. Woelfle, J.; Chia, D.J.; Massart-Schlesinger, M.B.; Moyano, P.; Rotwein, P. Molecular physiology, pathology, and regulation of the growth hormone/insulin-like growth factor-I system. Pediatr. Nephrol. 2005, 20, 295-302. [CrossRef] [PubMed]

35. Woelfle, J.; Chia, D.J.; Rotwein, P. Mechanisms of growth hormone (GH) action. Identification of conserved Stat5 binding sites that mediate GH-induced insulin-like growth factor-I gene activation. J. Biol. Chem. 2003, 278, 51261-51266. [CrossRef] [PubMed]

36. Woelfle, J.; Rotwein, P. In vivo regulation of growth hormone-stimulated gene transcription by STAT5b. Am. J. Physiol. Endocrinol. Metab. 2004, 286, E393-E401. [CrossRef] [PubMed]

37. Chia, D.J.; Ono, M.; Woelfle, J.; Schlesinger-Massart, M.; Jiang, H.; Rotwein, P. Characterization of distinct Stat $5 \mathrm{~b}$ binding sites that mediate growth hormone-stimulated IGF-I gene transcription. J. Biol. Chem. 2006, 281, 3190-3197. [CrossRef] [PubMed]

38. Vidal, O.M.; Merino, R.; Rico-Bautista, E.; Fernandez-Perez, L.; Chia, D.J.; Woelfle, J.; Ono, M.; Lenhard, B.; Norstedt, G.; Rotwein, P.; et al. In vivo transcript profiling and phylogenetic analysis identifies suppressor of cytokine signaling 2 as a direct signal transducer and activator of transcription $5 b$ target in liver. Mol. Endocrinol. 2007, 21, 293-311. [CrossRef] [PubMed]

39. Woelfle, J.; Billiard, J.; Rotwein, P. Acute control of insulin-like growth factor-I gene transcription by growth hormone through Stat5b. J. Biol. Chem. 2003, 278, 22696-22702. [CrossRef] [PubMed]

40. Rotwein, P.; Billiard, J.; Woelfle, J. Molecular physiology of IGF-I expression. J. Pediatr. Endocrinol. Metab. 2002, 15 (Suppl. 5), 1455-1458. [PubMed]

41. Woelfle, J. Wachstumshormoninsensitivität und schwerer primärer Mangel an insulinähnlichem Wachstumsfaktor-1: Behandlung im Kindesalter. Monatsschrift Kinderheilkunde 2014, 162, 309-314. [CrossRef]

42. Schreiner, F.; Schoenberger, S.; Koester, B.; Domené, H.M.; Woelfle, J. Novel acid-labile subunit (IGFALS) mutation p.T145K (c.434C > A) in a patient with ALS deficiency, normal stature and immunological dysfunction. Horm. Res. Paediatr. 2013, 80, 424-430. [CrossRef] [PubMed]

43. Bang, P.; Polak, M.; Woelfle, J.; Houchard, A.; EU IGFD Registry Study Group. Effectiveness and Safety of rhIGF-1 Therapy in Children: The European Increlex ${ }^{\circledR}$ Growth Forum Database Experience. Horm. Res. Paediatr. 2015, 83, 345-357. [CrossRef] [PubMed]

44. Ranke, M.B.; Wölfle, J.; Schnabel, D.; Bettendorf, M. Treatment of dwarfism with recombinant human insulin-like growth factor-1. Dtsch. Arztebl. Int. 2009, 106, 703-709. [CrossRef] [PubMed]

45. Ardon, O.; Procter, M.; Tvrdik, T.; Longo, N.; Mao, R. Sequencing analysis of insulin receptor defects and detection of two novel mutations in INSR gene. Mol. Genet. Metab. Rep. 2014, 1, 71-84. [CrossRef] [PubMed]

46. Longo, N.; Wang, Y.; Smith, S.A.; Langley, S.D.; DiMeglio, L.A.; Giannella-Neto, D. Genotype-phenotype correlation in inherited severe insulin resistance. Hum. Mol. Genet. 2002, 11, 1465-1475. [CrossRef] [PubMed]

47. Ben Abdelaziz, R.; Ben Chehida, A.; Azzouz, H.; Boudabbous, H.; Lascols, O.; Ben Turkia, H.; Tebib, N. A novel homozygous missense mutation in the insulin receptor gene results in an atypical presentation of Rabson-Mendenhall syndrome. Eur. J. Med. Genet. 2016, 59, 16-19. [CrossRef] [PubMed]

48. De Kerdanet, M.; Caron-Debarle, M.; Nivot, S.; Gaillot, T.; Lascols, O.; Fremont, B.; Bonnaure-Mallet, M.; Gie, S.; Massart, C.; Capeau, J. Ten-year improvement of insulin resistance and growth with recombinant human insulin-like growth factor 1 in a patient with insulin receptor mutations resulting in leprechaunism. Diabetes Metab. 2015, 41, 331-337. [CrossRef] [PubMed]

49. Kirkwood, A.; Stuart, G.; Harding, L. Donohue syndrome: A review of literature, case series, and anesthetic considerations. Pediatr. Anesth. 2018, 28, 23-27. [CrossRef] [PubMed]

50. Simpkin, A.; Cochran, E.; Cameron, F.; Dattani, M.; de Bock, M.; Dunger, D.B.; Forsander, G.; Guran, T.; Harris, J.; Isaac, I.; et al. Insulin receptor and the kidney: Nephrocalcinosis in patients with recessive INSR mutations. Nephron Physiol. 2014, 128, 55-61. [CrossRef] [PubMed]

51. Tiwari, S.; Sharma, N.; Gill, P.S.; Igarashi, P.; Kahn, C.R.; Wade, J.B.; Ecelbarger, C.M. Impaired sodium excretion and increased blood pressure in mice with targeted deletion of renal epithelial insulin receptor. Proc. Natl. Acad. Sci. USA 2008, 105, 6469-6474. [CrossRef] [PubMed] 
52. Accili, D.; Drago, J.; Lee, E.J.; Johnson, M.D.; Cool, M.H.; Salvatore, P.; Asico, L.D.; José, P.A.; Taylor, S.I.; Westphal, H. Early neonatal death in mice homozygous for a null allele of the insulin receptor gene. Nat. Genet. 1996, 12, 106-109. [CrossRef] [PubMed]

53. Ogilvy-Stuart, A.L.; Soos, M.A.; Hands, S.J.; Anthony, M.Y.; Dunger, D.B.; O’Rahilly, S. Hypoglycemia and resistance to ketoacidosis in a subject without functional insulin receptors. J. Clin. Endocrinol. Metab. 2001, 86, 3319-3326. [CrossRef] [PubMed]

54. Wertheimer, E.; Lu, S.; Backeljauw, P.F.; Davenport, M.L.; Taylor, S.I. Homozygous deletion of the human insulin receptor gene results in leprechaunism. Nat. Genet. 1993, 5, 71-73. [CrossRef] [PubMed]

55. Fukunaga, T.; Murakami, T.; Tanaka, H.; Miyawaki, S.; Yamashiro, T.; Takano-Yamamoto, T. Dental and craniofacial characteristics in a patient with leprechaunism treated with insulin-like growth factor-I. Angle Orthod. 2008, 78, 745-751. [CrossRef]

56. Bathi, R.J.; Parveen, S.; Mutalik, S.; Rao, R. Rabson-Mendenhall syndrome: two case reports and a brief review of the literature. Odontology 2010, 98, 89-96. [CrossRef] [PubMed]

57. Musso, C.; Cochran, E.; Moran, S.A.; Skarulis, M.C.; Oral, E.A.; Taylor, S.; Gorden, P. Clinical course of genetic diseases of the insulin receptor (type A and Rabson-Mendenhall syndromes): A 30-year prospective. Medicine 2004, 83, 209-222. [CrossRef] [PubMed]

58. Abe, Y.; Watanabe, T. Renal tubular dysfunction in patients with molecular defects of the insulin receptor gene. Eur. J. Pediatr. 2014, 173, 263. [CrossRef] [PubMed]

59. Abe, Y.; Sato, T.; Takagi, M.; Watanabe, T.; Nagayama, Y.; Hasegawa, T.; Abe, T. A case of Rabson-Mendenhall syndrome with a novel mutation in the tyrosine kinase domain of the insulin receptor gene complicated by medullary sponge kidney. J. Pediatr. Endocrinol. Metab. 2012, 25, 587-590. [CrossRef] [PubMed]

60. Baqir, Z.S.; Al-Lawati, T.T.; Al Hussaini, S.O.; Al-Sinani, A.; Al-Said, K.; Al-Rashdi, I. A novel leprechaunism mutation, Cys807Arg, in an Arab infant: a rare cause of hypoglycaemia. Paediatr. Int. Child Health 2012, 32, 183-185. [CrossRef] [PubMed]

61. Hovnik, T.; Brantanic, N.; Podkrajšek, K.T.; Kovač, J.; Paro, D.; Podnar, T.; Bratina, N.; Battelino, T. Severe progressive obstructive cardiomyopathy and renal tubular dysfunction in Donohue syndrome with decreased insulin receptor autophosphorylation due to a novel INSR mutation. Eur. J. Pediatr. 2013, 172, 1125-1129. [CrossRef] [PubMed]

62. Desbois-Mouthon, C.; Magré, J.; Duprey, J.; Caron, M.; Blivet-Van Eggelpoel, M.J.; Daubas, C.; Gourmelen, M.; Chevallier, B.; Rizkalla, S.; Robert, J.J.; et al. Major circadian variations of glucose homeostasis in a patient with Rabson-Mendenhall syndrome and primary insulin resistance due to a mutation(Cys ${ }^{284} \rightarrow$ Tyr) in the insulin receptor alpha-subunit. Pediatr. Res. 1997, 42, 72-77. [CrossRef] [PubMed]

63. Longo, N.; Singh, R.; Elsas, L.J. Decreased half-life of insulin-like growth factor I in Rabson-Mendenhall syndrome. J. Inherit. Metab. Dis. 2001, 24, 546-550. [CrossRef] [PubMed]

64. Carrasco de la Fuente, M.; Barrio Castellanos, R.; Alonso Blanco, M.; de la Calle Blasco, H. Long survival in Rabson-Mendenhall syndrome. Diabetes Res. Clin. Pract. 2010, 89, e17-e18. [CrossRef] [PubMed]

65. Moreira, R.O.; Zagury, R.L.; Nascimento, T.S. Multidrug therapy in a patient with Rabson-Mendenhall syndrome. Diabetologia 2010, 53, 2454-2455. [CrossRef] [PubMed]

66. Chong, Y.H.; Taylor, B.J.; Wheeler, B.J. Renal manifestations of severe Rabson-Mendenhall syndrome: A case report. J. Diabetes Metab. Disord. 2013, 12, 7. [CrossRef] [PubMed]

67. Moore, M.M.; Bailey, A.M.; Flannery, A.H.; Baum, R.A. Treatment of diabetic ketoacidosis with intravenous U-500 insulin in a patient with Rabson-Mendenhall syndrome: A case report. J. Pharm. Pract. 2017, 30, 468-475. [CrossRef] [PubMed]

68. Skarulis, M.C.; Celi, F.S.; Mueller, E.; Zemskova, M.; Malek, R.; Hugendubler, L.; Cochran, C.; Solomon, J.; Chen, C.; Gorden, P. Thyroid hormone induced brown adipose tissue and amelioration of diabetes in a patient with extreme insulin resistance. JCEM 2010, 95, 256-262. [CrossRef] [PubMed]

69. Gorden, P.; Zadeh, E.S.; Cochran, E.; Brown, R.J. Syndromic insulin resistance: Models for the therapeutic basis of the metabolic syndrome and other targets of insulin resistance. Endocr. Pract. 2012, 18, 763-771. [CrossRef] [PubMed]

70. LeRoith, D.; Yakar, S. Mechanisms of disease: Metabolic effects of growth hormone and insulin-like growth factor 1. Nat. Clin. Pract. Endocrinol. Metab. 2007, 3, 302-310. [CrossRef] [PubMed]

71. Chen, Z.H.; Li, T.; Chen, Z.B.; Luo, B.; Sun, R.P. Prevention of beta cell dysfunction and apoptosis by adenoviral gene transfer of rat insulin-like growth factor 1. Chin. Med. J. 2009, 122, 2159-2164. [PubMed] 
72. Escribano, O.; Guillén, C.; Nevado, C.; Gómez-Hernández, A.; Kahn, C.R.; Benito, M. Beta-Cell hyperplasia induced by hepatic insulin resistance: Role of a liver-pancreas endocrine axis through insulin receptor A isoform. Diabetes 2009, 584, 820-828. [CrossRef] [PubMed]

73. Kuzuya, H.; Matsuura, N.; Sakamoto, M.; Makino, H.; Sakamoto, Y.; Kadowaki, T.; Suzuki, Y.; Kobayashi, M.; Akazawa, Y.; Nomura, M.; et al. Trial of insulin like growth factor I therapy for patients with extreme insulin resistance syndromes. Diabetes 1993, 42, 696-70572. [CrossRef] [PubMed]

74. Bondy, C.A.; Underwood, L.E.; Clemmons, D.R.; Guler, H.P.; Bach, M.A.; Skarulis, M. Clinical uses of insulin-like growth factor I. Ann. Intern. Med. 1994, 120, 593-601. [CrossRef] [PubMed]

75. Backeljauw, P.F.; Alves, C.; Clemmons, D.R.; Guler, H.P.; Bach, M.A.; Skarulis, M. Effect of intravenous insulin-like growth factor I in two patients with leprechaunism. Pediatr. Res. 1994, 36, 749-754. [CrossRef] [PubMed]

76. Kawashima, Y.; Nishimura, R.; Utsunomiya, A.; Kagawa, R.; Funata, H.; Fujimoto, M.; Hanaki, K.; Kanzaki, S. Leprechaunism (Donohue syndrome): A case bearing novel compound heterozygous mutations in the insulin receptor gene. Endocr. J. 2013, 60, 107-112. [CrossRef] [PubMed]

77. Jo, W.; Sudo, S.; Nakamura, A.; Endo, D.; Konno, Y.; Ishizu, K.; Tajima, T. Development of endometrial carcinoma in a patient with leprechaunism (donohue syndrome). Clin. Pediatr. Endocrinol. 2013, 22, $33-38$. [CrossRef] [PubMed]

78. Kitamei, H.; Yokoi, M.; Kase, M.; Ohno, S. Retinal neovascularization during treatment with IGF-1 for insulin resistance syndrome. Graefes Arch. Clin. Exp. Opthalmol. 2005, 243, 715-717. [CrossRef] [PubMed]

79. Regan, F.M.; Williams, R.M.; McDonald, A.; Umpleby, A.M.; Acerini, C.L.; O’Rahilly, S.; Hovorka, R.; Semple, R.K.; Dunger, D.B. Treatment with recombinant human insulin-like growth factor (rhIGF)-I/rhIGF binding protein-3 complex improves metabolic control in subjects with severe insulin resistance. JCEM 2010, 95, 2113-2122. [PubMed]

80. Ranke, M.B. Insulin-like growth factor-I treatment of growth disorders, diabetes mellitus and insulin resistance. Trends Endocrinol. Metab. 2005, 16, 190-197. [CrossRef] [PubMed]

81. Brisigotti, M.; Fabbretti, G.; Pesce, F.; Gatti, R.; Cohen, A.; Parenti, G.; Callea, F. Congenital bilateral juvenile granulosa cell tumor of the ovary in leprechaunism: A case report. Pediatr. Pathol. 1993, 13, 549-558. [CrossRef] [PubMed] 